Ana Dili Eğitimi Dergisi
Journal of Mother Tongue Education
ADED - JOMTE
www.anadiliegitimi.com

\title{
Açık Öğretim Ortaokulu Altıncı Sınıf Türkçe Ders Notunun Metin Türleri ve Öğrenme
}

\author{
Alanları Açısından İncelenmesi
}

Hatice Altunkaya ${ }^{*}$

Özet

\begin{abstract}
Açık Öğretim Ortaokulu, örgün ortaokullarda yürütülen öğretim programlarıyla aynı programın esas alınarak öğretimin yapıldığı, ancak uzaktan eğitim teknikleriyle bu programın yürütüldüğü öğretim sistemidir. Bu okullarda öğrenim gören öğrenciler dönem sonu sınavlarına Millî Eğitim Bakanlığı Eğitim Teknolojileri Genel Müdürlüğü tarafından hazırlanan ders notları ile hazırlanmaktadırlar. Bu çalışmada, MEB tarafından ders notu olarak hazırlanmış olan 6 . sınıf Türkçe Ders Notundaki metin türleri ve öğrenme alanları incelenerek değerlendirilmiştir. Örgün öğretimdeki Türkçe ders programı temel alınarak hazırlanan Açık Öğretim Ortaokulu Türkçe Ders Notunun, Illköğretim Türkçe $(6,7,8$. Sınıflar) ders programında verilmesi gerektiği ifade edilen türlerden altısını barındırdığı, ancak fabl ve mektup türünde herhangi bir türü barındırmadığı görülmüştür. Türkçe 6 Ders Notu'nda Türkçe dersi öğrenme alanlarından okuma, yazma, konuşma ve dil bilgisi alanlarına yönelik Okuyalım Anlayalım, Konuşalım, Yazalım ve Dil Bilgisi bölümlerinin bulunmasına karşlık dinleme eğitimi ile ilgili bir bölümün bulunmadığı tespit edilmiştir.
\end{abstract}

Anahtar Kelimeler: açık öğretim ortaokulu, ders notu, uzaktan eğitim.

\section{Analyzing the Text Types and Learning Domains in Sixth Grade Turkish Course Lecture Notes of Distant Learning Secondary Schools}

\begin{abstract}
The Distant learning based secondary school is a system of education, in which the education commences based on the same programs that are conducted in formal secondary school but in which such programs are conducted via distant learning methods. Students, who receive education in such schools, prepare their end of term examinations by the lecture notes, compiled by Ministry of Education General Directorate for Education Technologies. In this study, the text types and learning domains in the sixth grade Turkish Course lecture notes, compiled by MoE as lecture notes, are analyzed and evaluated. It is revealed that the Distant learning based Secondary school Turkish Corse Lecture notes, which are based on the Turkish Course Curriculum of formal secondary schools, include six of the types that are required to be presented in the curriculum of Elementary Turkish courses $(6,7,8$ th Grades) as stated, however it was also revealed that they do not contain any types in genres of fable and letter. Although the sections of Lets read, lets understand, lets speak, lets write and grammar from the Turkish Courses learning domains in Turkish 6 Lecture notes, are present; it was also ascertained that no sections regarding training for were included.

Keywords: distant learning based secondary school, lecture notes, distant learning
\end{abstract}

\footnotetext{
* Doktora Öğrencisi. İnönü Üniversitesi, Eğitim Bilimleri Enstitüsü, Türkçe Eğitimi Ana Bilim Dalı. E-posta: hatice4473@hotmail.com
} 


\section{Giriş}

Açık Öğretim Ortaokulu, çeşitli sebeplerle ortaokula devam edemeyen ve zorunlu ortaokul yaş sınırını aşarak örgün eğitim-öğretim sisteminin dışında kalan bireylere uzaktan eğitim ilke ve yöntemleriyle her durumda, her yerde eğitim-öğretim imkânı vermek; bu eğitim sayesinde toplumun kültür düzeyini yükseltmek; mezun olan öğrencilerin meslek edinmelerini kolaylaştırmak ve onları bir üst öğrenime hazırlamak amacı güden eğitim sisteminin ilk basamağıdır.

1998- 1999 eğitim öğretim yılında 68 bin 886 öğrenciyle yola çıkan Açık İlköğretim Okulu aynı dönemde 2 bin 897 öğrenci mezun etmiştir. Kuruluşunun 14. yılında aktif öğrenci sayısı 250 bini aşmış, mezun sayısı ise 410 bin 859 olmuştur. Mezun olan öğrencilerden yaklaşık 200 bin kişi Açık Öğretim Lisesi ve Mesleki Açık Öğretim Lisesi'ne kayıt yaptırarak bir üst kademeye devam etmiştir (http://aio.meb.gov.tr/sayfa.php?id=53).

250 bini aşan aktif öğrenci sayısının bulunduğu bir öğretim sisteminde, öğretim programlarında belirlenen amaçlara ulaşılabilmesi için temel eğitim kaynaklarının titizlikle hazırlanması gerekmektedir. Bireylerin öğrenme sorumluluğunun kendi üzerlerinde olduğu uzaktan eğitim sisteminde hazırlanacak Türkçe kitaplarında yer alacak metin türlerinin önemli bir yeri olmasının yanı sıra temel becerilerin bu metinler aracılığıyla kazandırılacak olması da öğretim materyali olarak kullanılan ders notlarına alınacak metinlerin niteliğinin önemine işaret etmektedir.

Türkçe dersinin amaç ve kazanımlarının öğrencilere kazandırılabilmesi için kullanılan temel kaynak örgün eğitimde ders kitapları, Açık Öğretim Ortaokulu'nda ders notlarıdır. Ders kitapları, öğretim programları ve Türk Millî Eğitiminin genel amaçları ve temel ilkeleri doğrultusunda hazırlanan özellikle Türkçe dersi için Türk ve dünya edebiyatının seçkin eserlerinden derlenen zengin metinlerin bulunduğu temel eğitim ve öğretim kaynaklarıdır.

Ortaokullardaki Türkçe dersinin genel amacı; Türkçe Dersi Öğretim Programı ile Türk Millî Eğitiminin genel amaçları ve temel ilkelerine uygun olarak öğrencilerin Türkçeyi, konuşma ve yazma kurallarına uygun olarak bilinçli, doğru, özenli kullanmalarını sağlayarak okuma, yazma, konuşma ve dinleme/izleme alışkanlığı kazanmalarını, söz varlıklarını zenginleştirmelerini, duygularını, hayallerini, düşüncelerini sözlü ve yazılı olarak ifade edebilmelerini sağlamaktır.

Ders kitapları, öğrencilerin dil becerilerine ait öğrenme alanlarındaki kazanımları farkındalık düzeyine ulaştırmada önemli bir işlevi yerine getirmektedir. Dil farkındalığı oluşturmada ders kitabı önemli bir araçtır. Ders kitapları aynı zamanda, programdaki kazanımların içerdiği bilgi ve becerileri davranışa dönüştürmede de etkili bir araçtır. Ders kitaplarında yer alan etkinlikler, açık bilgiyi örtük bilgiye dönüştürme işlevini yerine getirmektedir (Onan;2012:68). 
Açık Öğretim Ortaokulu Altıncı Sınıf Türkçe Ders Notunun Metin Türleri ve Öğrenme Alanları Açısından incelenmesi

Sever (2004), Türkçe öğretiminin genellikle yazınsal ve öğretici nitelikli metinlerle yapıldığını; bu metinlerin öğretimin temel araçları olduğunu; Türkçenin akıcılığı, yalınlığı, deyimleme ve mecaz gücü ile duygu ve düşünce zenginliğinin yansıtıldığı metinlerle gerçekleştirilen çalışma ve incelemelerin öğrencilere yaşantı zenginliği kazandırdı̆̆ını belirtmektedir.

Okurken, yazarken, dinlerken, konuşurken ve bilginin her düzeyinde edebî metinler araç olarak kullanılmaktadır. Yazılı ve sözlü eserler aracılığı ile öğrencilerin okuma, dinleme, yazma ve konuşma düzeylerini geliştirmenin yanında, onların geniş konu alanlarına yönelmeleri, farklı disiplinlerle ilgi kurmaları ve daha önemlisi birey olabilme sorumluluğu edinebilmesi amaçlanmaktadır (Aytaş; 2006:261).

Ders kitaplarına alınan metinlerin çeşitli özellikleri yanında türlerinin de eğitim açısından önemli bir yeri vardır. Türlerle ilgili bilginin kavratılması salt tür bilgisi, türün özellikleri vs. değildir. Türün taşıdığı dil ve anlatım özellikleri de bu yolla kavratılabilir. Masalla, öğrenilen geçmiş zaman kipi; hikâyeyle anlatım biçimi olarak betimleme ve betimleme sonrasında sıfatlar, zarflar; makaleyle açıklama; şiirle mecazlar ve söz sanatlarını kavratmak mümkündür. Dolayısıyla Türkçe dersleri açısından metinleri ve bu metinlerin türlerini, yalnızca belli kazanımlara ulaşmak için kullanılan araçlar olarak görmemek gerekir (Çeçen ve Çiftçi; 2007:41).

Türkçe dersi bilgi kazandırmaktan daha ziyade anlama ve anlatma becerilerinin geliştirilmesini temel alan bir derstir. Yapılandırmacı yaklaşım tarzı esas alınarak hazırlanan Türkçe Dersi Öğretim Programı'nda (MEB,2006:2) yer alan “Türkçe öğrenimi, anlama, yorumlama, iletişim kurma becerilerinin gelişmesine yönelik olan dinleme/izleme, konuşma, okuma, yazma öğrenme alanları ile dil bilgisinden oluşur. Sözü geçen öğrenme alanları birbiriyle etkileşim hâlinde olduğundan bir bütünlük içinde ele alınmalıdır. Dil öğretiminin temel hedefi, öğrencilerin, dilin farklı bağlamlarda aldığı görünümleri kavramaları, dil aracılığıyla kendilerini ifade edebilmeleri, değişik bilgi kaynaklarına ulaşarak duygu, düşünce ve hayal dünyalarını zenginleştirmeleridir" ifadeleri Türkçe dersine ait öğrenme alanlarının bir bütünlük içerisinde verilmesinin gerekliliğine işaret edilmektedir. Böylelikle kendilerini etkili bir şekilde sözel ve yazılı olarak ifade edebilen, düşünen, sorgulayan, eleştiren, görev ve sorumluluklarının bilincinde olan nesillerin yetiştirilmesinin hedeflendiği düşünülebilir.

Türkçe dersinin temel kaynağı olan ders kitapları örgün eğitimde Türkçe dersi amaç ve kazanımlarını sağlamada kullanılan birincil kaynaklardır. Açık Öğretim sistemiyle öğrenim gören öğrenciler için de Millî Eğitim Bakanlığı tarafından verilen ders notları, öğrencilerin ana dillerine ait temel dil becerilerini edinebilmelerinde ve dönem sonu sınavlarına hazırlanmalarında yararlandıkları temel kaynaktır. 


\section{Problem Cümlesi}

Alan yazınına bakıldığında örgün öğretimde kullanılan Türkçe ders kitapları üzerinde çok sayıda çalışmanın yapıldığı, ancak 250 binin üzerinde öğrencisi bulunan Açık Öğretim Okulu temel ders kaynağı olan ders notları üzerinde bir araştırmanın bulunmadığı görülmektedir. Bu çalışmada “Açık Öğretim Ortaokulu 6. sınıf Türkçe ders notunda hangi türlere ve Türkçe dersi temel beceri alanlarından hangilerine yer verilmiştir?" sorusunun cevabı bulunmaya çalışılmıştır.

\section{Yöntem}

Yöntem bölümünde araştırmanın modeli, evreni, veri toplama teknikleri ve verilerin analizi yer almaktadır.

\section{Araştırma Modeli}

Açık Öğretim Ortaokulu 6. sınıf ders notunda yer alan metinleri tür yönüyle inceleyerek bu metinlerden hareketle verilen temel becerilerin hangileri olduğunu tespit etmeyi amaçlayan bu çalışma, nitel araştırmalardan doküman incelemesine göre yapılmıştır. Şimşek ve Yıldırım (2011), doküman incelemesinin, araştırılması hedeflenen olgu ve olgular hakkında bilgi içeren yazılı materyallerin analizini kapsadığını belirtmişlerdir.

\section{Çalışma Evreni}

Araştırmanın evrenini Millî Eğitim Bakanlığı Eğitim Teknolojileri Genel Müdürlüğü tarafından hazırlatılarak Açık Öğretim Ortaokullarında 6. sınıf Türkçe ders notu olarak kayıt yaptıran öğrencilere ücretsiz verilen ders notundaki 16 metin ve bu metinler doğrultusunda ele alınan Türkçe dersi öğrenme alanları oluşturmaktadır. Çalışmada örneklem alınmamış, evrenin tamamı üzerinde çalışılmıştır.

\section{Verilerin Toplanması ve Analizi}

Araştırmada veri toplama aracı olarak M.E.B. Eğitim Teknolojileri Genel Müdürlüğü Yayınları Açık Öğretim Okulları Ders Kitapları Dizisi içinde bulunan Mine Solmaz tarafından hazırlanan Türkçe 6 Ders Notu kullanılmıştır. Ders notunda bulunan türler ve öğrenme alanları ders notunda yer alan açıklamalar doğrultusunda tespit edilmiştir.

Araştırmada toplanan veriler frekans hesaplamaları kullanılarak sınıflandırılmıştır.

\section{Bulgular ve Yorum}

Bu bölümde araştırma kapsamında elde edilen bulgular, "6. sınıf Türkçe Ders notunda yer alan metinlerin türleri ve bu türlerin ders notuna göre kullanım sıklığı nedir?" ile "6. sınıf Türkçe Ders 
Açık Öğretim Ortaokulu Altıncı Sınıf Türkçe Ders Notunun Metin Türleri ve Öğrenme Alanları Açısından incelenmesi

notunda Türkçe dersi temel beceri alanları olan okuma, yazma, konuşma ve dinleme becerilerinden hangilerine yer verilmiştir?" soruları çerçevesinde sunulmuş ve yorumlanmıştır.

Açık Öğretim Okulu 6. Sınıf Türkçe Ders Notunda toplam 16 metin yer almıştır. Bu metinlerden 6 tanesi deneme, 2 tanesi hikâye, 2 tanesi şiir, birer tanesi de masal, tiyatro, biyografi, anı, fıkra (köşe yazısı) ve söyleşi türüne ait metinlerdir. Illköğretim Türkçe Dersi $(6,7,8$. sınıflar) Öğretim Programı'nda 6. sınıfta şiir, hikâye, anı, masal, fabl, deneme, tiyatro, mektup türlerinin verilmesinin gerekli olduğu belirtilmektedir (MEB,2006). Bu durumda araştırma kapsamında ele alınan ders notunun fabl ve mektup türünü barındırmaması, öğrencilerin bu türlere ait özellikleri kavrayabilmeleri noktasında bir eksiklik oluşturacaktır.

Tablo 1: Açık Öğretim Ortaokulu 6. Sınıf Türkçe Ders Notunda Yer Alan Metinlerin Türleri ve Bu Türlerin Kitaba Göre Kullanım Sıklığı

\begin{tabular}{lll}
\hline Metnin Adı & Metnin Türü & Sayfa Nu. \\
\hline Kedi & Deneme & 3 \\
Hırsız Taş & Masal & 13 \\
Atatürk ve Tarih & Deneme & 35 \\
Atatürk'ün Hayatı & Biyografi & 46 \\
Mustafa Kemal & Şiir & 56 \\
Sevgi Güzelliktir & Söyleşi & 65 \\
Sevgi & Deneme & 75 \\
Vatan & Şiir & 84 \\
Kurabiye Hırsızı & Hikâye & 99 \\
Iş̧itmek ve Dinlemek & Deneme & 107 \\
Teknolojik Bayram & Deneme & 113 \\
Kutlamaları & & \\
Atatürk'ün Ağaç Sevgisi & Anı & 133 \\
Çevre Kirliliği & Fıkra (köşe yazısı) & 146 \\
Son Kuşlar & Hikâye & 155 \\
Alışkanlık & Deneme & 173 \\
Karagöz & Tiyatro (gölge oyunu) & 179 \\
\hline
\end{tabular}

Açık Öğretim Ortaokulu Ders Notu altı üniteden oluşmaktadır. Birinci ve altıncı ünitede ikişer, ikinci, üçüncü ve dördüncü ünitelerde üçer metin yer almaktadır. Metin işleniş sürecinde ders notunda her metne ait Okumaya Hazırlık, Okuyalım Anlayalım, Konuşalım, Yazalım ve Dil Bilgisi bölümleri yer almaktadır. Ünite sonlarında ünitede ele alınan konulara ilişkin bir özet bölümü ve çoktan seçmeli test yer almıştır.

Birinci ünitede yer alan "Kedi" adlı metin Nurullah Ataç’ın "Günlerin Getirdiği" adlı eserinden alınmıştır. Metin öncesi Okumaya Hazırlık bölümü, metin sonrasında da Okuyalım Anlayalım, Konuşalım, Yazalım ve Dil Bilgisi bölümleri yer almıştır. Okuyalım Anlayalım bölümünde noktalama işaretleri doğrultusunda okuma kuralları verilmiş ve bu kurallara dikkat ederek okumanın anlamaya 
katkısı ifade edilmiştir. Okuma becerileri kazandırma doğrultusunda hazırlanan çalışma kâğıtları metni takip eden sayfalarda yer almaktadır. Konuşalım bölümünde işlenen metin konusuyla ilgili bir konu verilerek ilgili konuda öğrencilerden çevrelerindeki insanlarla tartışmaları istenmiştir. Yazalım bölümünde metnin türü deneme olarak belirtilerek türün tanımı yapılmış, türe ait özellikler hakkında bilgi verilmiştir. Yazalım bölümünün devamında paragraf ve kompozisyon hakkında bilgi verilerek hazırlanan çalışma kâğıtlarında öğrencilerin örnek paragraflardan hareketle paragraf yazmaları ve önerilen yönergeler doğrultusunda metin konusu ile ilişkili bir konu verilerek bir kompozisyon yazmaları istenmiştir. Dil Bilgisi bölümünde Türkçe'nin sesli harfleri hakkında bilgiler verilerek kalınlık incelik uyumu kuralı tanımlanmış ve sonrasında yer alan konuyla ilgili çalışma kâğıdında Cahit Külebi’ye ait "Köy Öğretmenleri” adlı şiir metni verilerek öğrencilerden bu şiirde geçen kalınlık-incelik uyumuna aykırı sözcükleri bulmaları istenmiştir. Metin sonunda yapılan temel beceriler arasında Türkçe dersi dört temel beceri alanından olan dinleme eğitimine ait herhangi bir bölümün bulunmaması bir eksiklik olarak görülmektedir.

"Hırsız Taş" adlı metin Gülten Suveren tarafından derlenen "Doğudan Seçme Masallar" adlı kitaptan alınmış olan masal metni olup birinci ünitenin ikinci metni olarak yer almaktadır. Masal metni öncesinde Okumaya Hazırlık bölümü yer almaktadır. Bu bölümde öğrencilere "metni okurken noktalama işaretlerine dikkat ediniz" yönergesi verilip metnin paragrafları arasında tahmin yürütmeleri için sorulan soruları metnin sorudan sonraki kısmını okumadan cevaplamaları istenmiştir. Paragraflar arasında 5 bölümde metinle ilgili sorular sorulmuş ve öğrencilerin cevaplarını yazabilecekleri alanlar bırakılmışır. Böylelikle öğrencilerin metinle ilgili tahminlerde bulunmaları hedeflenmiştir. Okuyalım Anlayalım bölümünde yer alan 5 bölümlük çalışma kâğıdında okuduğunu anlama becerisinin geliştirilmesine yönelik etkinlikler yer almaktadır. Konuşalım bölümünde okunan metnin türünün masal türü olduğu belirtilerek masal’ın tanımı yapılmış, türe ait özellikler hakkında bilgiler verilmiştir. Bu bölümde konuşma becerisi ile ilgili öğrencilere "metindeki çocuğun düştüğü durumu düşünerek yakınınızdaki insanlara başlarından böyle bir olay geçip geçmediğini sorunuz. Başından böyle bir olay geçen insanlara neler hissettiklerini anlattırınız" yönergesiyle öğrencilerin kendini sözlü olarak ifade etme amacı doğrultusunda merak ettiğini sorma kazanımı elde etmeleri sağlanmaya çalışılmıştır. Yazalım bölümünde öğrencilerden, masal karakterinin yerine kendilerini koyarak bu karakterin yaşadığı olayı yaşamış olmaları hâlinde neler hissedebileceklerini öfkeli, yalnız, kuşkucu, yardımsever, sevinçli, heyecanlı sözcüklerini de kullanarak bir yazı yazmaları istenmiştir. Dil Bilgisi bölümünde ünsüz harfler ve özellikleri ile Türkçedeki ses olaylarına ilişkin bilgiler verilerek 4 bölümlük çalışma kâğıdı aracılı̆ııla bu bilgilerin pekiştirilmesi hedeflenmiştir. Türkçe dersi dört temel beceri alanından okuma, konuşma ve yazma alanına ait becerilerin kazandırılması için bölümler 
Açık Öğretim Ortaokulu Altıncı Sınıf Türkçe Ders Notunun Metin Türleri ve Öğrenme Alanları Açısından incelenmesi

bulunan metnin sonunda dinleme becerisine ilişkin hiçbir bölüm, bilgi, amaç ya da kazanım yer almamıştır.

İkinci ünitenin ilk metni Bülent Kahraman Çolakoğlu tarafından yazılmış olan “Atatürk ve Tarih" adlı deneme türüne ait bir metindir. Okuyalım Anlayalım bölümünde okuduğunu anlamaya ilişkin beş bölümden oluşan çalışma kâğıdı yer almıştır. Konuşalım ve yazalım bölümünde birer konu verilerek o konular hakkında konuşulup yazılması önerilmiştir. Dil Bilgisi bölümünde sözcük ve sözcükte anlam konusu hakkında bilgi verilerek verilen bilgilerin 5 bölümlük çalışma kâğıdı etkinlikleriyle pekiştirilmesi hedeflenmiştir. Metin sonunda Türkçe dersi öğrenme alanlarından dinleme alanına ait herhangi bir bölüm bulunmaması, dinleme becerisinin ihmal edilen bir öğrenme alanı olarak görüldüğünü ortaya koymaktadır.

“Atatürk'ün Hayatı” adlı metin Hamza Eroğlu’nun Türk İnkılâp Tarihi adlı eserinden kısaltılarak alınmış biyografi türüne ait bir metindir. Metin sonunda yer alan Okuyalım Anlayalım bölümünde 4 bölümlük çalışma kâğıdı aracılığı ile okuduğunu anlamayı sağlayacak çeşitli etkinlik örnekleri yer almıştır. Konuşalım, Yazalım bölümü tek bir başlık altında ele alınarak okunan metin türünün biyografi olduğu belirtilmiş, türe ait özellikler hakkında bilgi verilmiştir. Konuşma kazanımına ait herhangi bir çalışma kâğıdının yer almadığı metin sonu çalışmalarında yazma alanına ait verilen çalışma kâğıdında, öğrencilerden tanıdıkları bir kişinin yaşam öyküsünü metindeki gibi yazmaları istenmiştir. Dil Bilgisi bölümünde deyimler, atasözleri ve özdeyişler hakkında bilgiler verilerek 6 bölümlük çalışma kâğıdı aracılığıyla bu bilgilerin pekiştirilmesi için etkinlikler sıralanmıştır.

İkinci ünitenin son metni serbest okuma metni olarak verilen Cahit Külebi’ye ait “Mustafa Kemal" adlı şiir metnidir. Serbest okuma metni sonrası ve öncesinde metinle ilgili bir çalışma yer almamıştır.

Üçüncü ünitenin ilk metni "Sevgi Güzelliktir” adlı metin İpek Ongun'un "Bir Pırıltıdır Yaşamak” adlı kitabından kısaltılarak alınmış söyleşi türünde bir metindir. Metnin Okumaya Hazırlık bölümünde öğrencilere "Sevgi deyince ne anlıyorsunuz? Sizce sevgi bize neler kazandırır?" sorusu yöneltilerek metin hakkında tahminde bulunmaları sağlanmaya çalışılmıştır. Okuyalım Anlayalım bölümünde yer alan 5 bölümlük çalışma kâğıdında metni anlama, yorumlama, söz varlığını zenginleştirme ile ilgili etkinlikler verilmiştir. Konuşalım bölümünde öğrencilere sevgi hakkında arkadaşlarıyla konuşmaları önerilmiş, Yazalım bölümünde ise beş değişik yazma konusu verilerek birini seçip o konu üzerine bir kompozisyon yazmaları istenmiştir.

Üçüncü ünitede yer alan ikinci metin Dr. Erdal Atabek'in "Kuşatılmış Gençlik” adlı kitabından kısaltılarak alınmış "Sevgi" adlı metindir. Metin öncesi Okumaya Hazırlık bölümü, metin sonunda Okuyalım Anlayalım, Konuşalım, Yazalım ve Dil Bilgisi öğrenme alanlarına ilişkin bilgiler ve etkinlik 
örnekleri yer almıştır. Okuyalım Anlayalım bölümü etkinliklerinde öğrencilerin Türkçe Öğretim Programı amaçlarından "Söz varlığını zenginleştirme" amacı doğrultusunda "Kelimeler arasındaki anlam ilişkilerini kavrayarak birbiriyle anlamca ilişkili kelimelere örnek verme ve aynı kavram alanına giren kelimeleri, anlam farklılıklarını dikkate alarak kullanma" (MEB;2006) kazanımlarını edinmelerini sağlayacak etkinliklere yer verilmiştir. Konuşalım bölümünde metnin türünün deneme olduğu belirtilerek öğrencilerden sevgi konusunda çevrelerindeki insanlarla tartışmaları, Yazalım bölümünde sevgi konusunda bir kompozisyon yazmaları istenmiştir. Dil Bilgisi bölümünde isim hâl ekleri konusunda bilgi verilip etkinlikler aracılığı ile bilgilerin pekiştirilmesi amaçlanmıştır. Bu metin sonunda yer alan çalışmalar arasında da dinlemeye ilişkin bölüm yer almamaktadır.

Üçüncü ünitenin son metni Nurettin Özdemir'e ait "Vatan" adlı şiirdir. Okumaya Hazırık bölümünde öğrencilere "Bülbülü altın kafese koymuşlar ille de vatanım demiş" sözü verilerek ne anladıkları sorulmuştur. Okuyalım Anlayalım bölümünde söz varlığını zenginleştirecek etkinlik örnekleri yer almış, bu etkinliklerde eş sesli kelimelerin tanımı yapılmış ve çalışma kâğıdında yer alan görseller yardımıyla eş sesli sözcüklerin kavratılması amaçlanmıştır. Konuşalım bölümünde güzel şiir okuma yöntemlerine değinilerek öğrencilerden vurgu, tonlama ve noktalama işaretlerine dikkat ederek sevdikleri bir şiiri okumaları, Yazalım bölümünde ise şiirin tanımı, ölçüsü, teması ve akrostiş şiir hakkında bilgiler verilip öğrencilerden sevgi kelimesi ile akrostiş bir şiir yazmaları istenmiştir. Dil bilgisi bölümünde iyelik ekleri ele alınarak gerekli bilgiler verilmiş ve bu bilgilerin pekiştirilebileceği etkinlik örnekleri yer almıştır. Bu metin sonunda da dinleme eğitimine ilişkin bir bölüm bulunmamaktadır.

Açık Öğretim Okulu 6. Sınıf Ders Notu'nun dördüncü ünitesinde yer alan ilk metin Doğan Cüceloğlu'nun "iletişim Donanımları" adlı kitabından alınan Valeri Cox tarafından yazılmış "Kurabiye Hırsızı" adlı hikâye, ikinci metin yine Doğan Cüceloğlu'na ait olan "İnsan İnsana” adlı kitaptan alınan "Iş̧itmek ve Dinlemek" adlı deneme, üçüncü metin ise Nuray Bartoscek tarafından yazılmış olan "Teknolojik Bayram Kutlamaları" adlı deneme metnidir. Bu ünitede yer alan metinlerin öncesinde Okumaya Hazırlık, sonrasında ise Okuyalım Anlayalım, Konuşalım, Yazalım ve Dil Bilgisi bölümleri yer alırken dinleme becerisine ilişkin herhangi bir bölüm bulunmamaktadır.

Ders notunun beşinci ünitesinde yer alan ilk metin Falih Rıfkı Atay'ın "Babanız Atatürk" adlı kitabından alınan "Atatürk'ün Ağaç Sevgisi" adlı anı türündeki metindir. İkinci metin Sait Faik Abasıyanık'ın "Son Kuşlar" adlı eserinden kısaltılarak alınmış olan aynı adlı hikâyedir. Bu metinlerin sonunda da diğer metinlerde yer alan öğrenme alanları yer alırken dinleme becerisine ilişkin herhangi bir bölüm yer almamıştır. 
Açık Öğretim Ortaokulu Altıncı Sınıf Türkçe Ders Notunun Metin Türleri ve Öğrenme Alanları Açısından incelenmesi

Açık Öğretim Okulu 6. Sınıf Ders Notu'nun son ünitesi olan altıncı ünitede Michel Montaıgne'e ait "Alışkanlık" adlı deneme metni ve Hayalî Küçük Ali'ye ait "Karagöz" adlı gölge oyunu metni yer almaktadır. Altıncı ünitede yine önceki bölümlerde yer alan öğrenme alanları yer alırken dinleme becerisine ait bir amaç ya da kazanımı sağlayacak bölümün yer almadığı görülmektedir.

Özbay $(2005 ; 14)$ dinlemenin en etkili öğrenme yollarından biri olarak kabul edildiğini ve kişiyi başarıya götüren beceriler başında geldiğini ifade ederek Türkçe dersinde dil becerileri arasında en aktif olarak kullanılan becerinin dinleme becerisi olduğunu belirtmiş ve bütün bunlar göz önünde bulundurulunca öğrenmenin ve başarının anahtarın dinleme becerisine bağlı olduğunun herkesçe kabul edildiğini dile getirmiştir. Özbay’ın (2005:14) da değindiği gibi dinleme becerisi diğer dil becerilerinin kazanılmasında da aktif rol oynayan bir beceri olması yönüyle büyük bir önem arz etmektedir.

\section{Sonuç ve Öneriler}

Millî Eğitim Bakanlığı Açık İlköğretim Okulu Yönetmeliği Beşinci Bölüm, Eğitim Öğretim 30. Maddesinde "Okulda, ilköğretim ders programlarının uygulanması esastır." ifadesi yer almaktadır (MEB. 2001). Bu maddeye göre bütün derslerde örgün eğitimde kullanılan öğretim programları esas alınmakta olduğundan ders materyallerinin bu doğrultuda hazırlanması gerekmektedir.

Açık Öğretim Ortaokulu sisteminde Millî Eğitim Bakanlığı ya da özel yayınlar tarafından yayınlanmış ders kitabı bulunmamaktadır. Eğitim öğretim, ders programları doğrultusunda hazırlanmaya çalışılan ders notları ile yürütülmektedir. Kayıt yaptıran öğrencilere Millî Eğitim Bakanlığı tarafından ücretsiz olarak verilen ders notları eğitim öğretim çalışmalarında kullanılan temel kaynaklardır. Ders notlarının "Sunu" başlığını taşıyan bölümünde " Uzaktan eğitim yolu ile eğitim görmekte olduğunuz Açık İlköğretim Okulu'nda, (Okulun adı 21/07/2012 Tarihinde Millî Eğitim Bakanlığı Açık İlköğretim Okulu Yönetmeliğinde Değişiklik Yapılmasına Dair Yönetmelik ile "Açık Öğretim Ortaokulu" olarak değişmiştir) Genel Müdürlük olarak sizlere sunduğumuz hizmetlerden birisi de ders notu mahiyetindeki kitaplarımızdır. Uzaktan eğitim ilkelerine uygun olarak hazırlanan bu ders materyali lise müfredat programlarına uygun olarak hazırlanmaktadır. Hazırlanan bu ders notlarımız, müfredat programlarında meydana gelen değişikliklere paralel olarak yenilenmekte ve güncelleştirilmektedir" ifadeleri yer almaktadır. Açık Öğretim Ortaokulu'na yönelik olarak hazırlanan ders notuna lise müfredat programına uygun kitap hazırlandığının ifade edilmesi büyük bir dikkatsizlik olarak değerlendirilebilir. Zira ders notu incelendiğinde birtakım eksiklikleri olmakla birlikte lise müfredat programı yerine 2006 Millî Eğitim Bakanlığı Illköğretim Türkçe Dersi (6, 7, 8. Sınıflar) Öğretim Programı́nın esas alındığı görülmektedir. 
Türkçe 6 Ders Notu'nda 6 deneme, 2 hikâye, 2 şiir, 1 masal, bir biyografi, 1 fıkra (düşünce yazısı), 1 söyleşi, 1 anı ve 1 tiyatro olmak üzere toplam 9 tür metin bulunmaktadır. İlköğretim Türkçe Dersi $(6,7,8$. sınıflar) Öğretim Programı'nda 6. sınıfta şiir, hikâye, anı, masal, fabl, deneme, tiyatro, mektup türlerinin verilmesinin gerekli olduğu belirtilmektedir (MEB,2006). Bu durumda, Türkçe 6 Ders Notu'nda fabl ve mektup türüne yer verilmeyişi ders programları ekseninde hazırlanan ders notu için bir eksiklik olarak değerlendirilebilir.

Türkçe dersi anlama ve anlatma becerileri ile dil bilgisi özel alanından oluşan bir derstir. Anlama becerileri içerisinde dinleme ve okuma, anlatma becerisi içerisinde de konuşma ve yazma becerileri yer alır. Türkçe 6 Ders Notu incelendiğinde okuma, yazma, konuşma ve dil bilgisi becerilerini kazandırmaya yönelik bilgilerin, etkinliklerin yer aldığı ancak dinleme eğitiminin tamamen göz ardı edildiği görülmektedir.

Çeçen ve Çiftçi (2007) "ilköğretim 6. Sınıf Türkçe Ders Kitaplarında Yer Alan Metinlerin Tür ve Tema Açısından İncelenmesi" başlıklı çalışmalarında 2006-2007 eğitim öğretim yılında okutulan üç ders kitabındaki metinleri tür ve tema açısından inceleyerek iki kitapta sekiz türe bir kitapta da 9 türe yer verildiğini tespit etmiştir. Solak ve Yaylı (2009) yaptıkları araştırmada MEB ve Koza Yayınlarınca yayınlanan ders kitaplarını incelemiş ve mutlaka yer verilmesi gereken türleri her iki kitabın da barındırdığını tespit etmişlerdir. Kolaç (2009), 1-5 ve 6-8. sınıflara ait Türkçe ders kitaplarında yer alan metinlerin niteliğini ve türlerine göre dağılımını incelemiştir. Üründü (2011) "6-8. Sınıf Türkçe Ders Kitaplarının Tema ve Metin Türü Yönünden İncelenmesi” başlıklı yüksek lisans tezinde, ders kitaplarının metin türü belirleme konusunda birtakım eksiklikler taşıdığını, özellikle deneme-söyleşimakale türlerinin yer yer birbirine karıştırıldığını ve bildirme yazısı, düşünce yazısı, öğretici metin gibi genel isimlerin kullanıldığını tespit etmiştir. Yapılan araştırmalarda örgün öğretimde kullanılan ders kitaplarının program doğrultusunda gerekli türleri barındırdığı görülürken aynı programın esas alındığı Açık Öğretim Okulu 6. Sınıf Türkçe Ders Notunun mektup ve fabl türünü barındırmaması öğretmenin olmadığı, bireylerin kendi kendilerine eğitim aldıkları bir sistemde bir eksiklik olarak görülmektedir. Hazırlanacak ders notlarında bu eksikliklerin giderilmesi öğrencilerin bütün türlerle tanışması bakımından yararlı olacaktır.

Türkçe dersi dört temel beceri alanı olan okuma, yazma, konuşma, dinleme ile dil bilgisi alanından oluşan bir derstir. Açık Öğretim Ortaokulu Türkçe 6 Ders Notunda bu beceri alanlarından okuma, yazma, konuşma ve dil bilgisi alanlarına yer verilirken dinleme becerisi inmal edilmiş, bu alana ait hiçbir amaç ve kazanım ders notu içinde yer almamıştır. Dinleme eğitimi göz ardı edilmeyecek kadar önemli bir beceri olduğundan bu becerinin hazırlanacak ders notlarında mutlaka ele alınması gerektiği düşünülmektedir. Ders notlarında dinleme becerisi yer almalı, öğrencilerin dinleme 


\section{Açık Öğretim Ortaokulu Altıncı Sınıf Türkçe Ders Notunun Metin Türleri ve Öğrenme Alanları Açısından İncelenmesi}

etkinlikleri yapabileceği seslendirilmiş metinlerin yer aldığı dinleme cd'leri ders notlarıyla birlikte kayıt yaptıran öğrencilere sunulmalıdır.

Açık Öğretim Ortaokulu için hazırlanacak ders notlarında, Türkçe dersi öğretim programında sınıf düzeyine göre yer alması gerekli bütün türlere yer verilmesi, türlerin bütün özelliklerinin kavranabilmesi açısından öğrencilerin yararına olacaktır.

Öğrenim yaşı geçmiş bireylerin öğrenim gördükleri Açık Öğretim Ortaokulu ve Açık Öğretim Liselerinde çok sayıda öğrenci uzaktan eğitim yoluyla öğrenimlerini devam ettirmektedirler. Yapılan uzaktan eğitimde temel kaynak olan ders notlarının alanında uzman akademisyenlerce araştırılarak eksikliklerinin tespit edilmesi ve bu eksikliklerin ders notlarını hazırlayanlarca dikkate alınması hâlinde eğitim öğretimde belirlenen temel hedeflere ulaşılabilecek nitelikli ders materyallerinin hazırlanacağı düşünülmektedir.

\section{Kaynakça}

Aytaş, G.(2006). Edebi türlerden yararlanma. Millî Eğitim, 169,261-276.

Çeçen, M.A. ve Çiftçi, Ö. (2007). Illköğretim 6. sınıf Türkçe ders kitaplarında yer alan metinlerin tür ve tema açısından incelenmesi. Milli Ĕgitim, 173, 39-49.

Kolaç, E. (2009). illköğretim Türkçe ders kitaplarında yer alan metinlerin tür açısından değerlendirilmesi. Uluslararası insan Bilimleri Dergisi, 6(1), 594-626.

MEB Açık İlköğretim Okulu Yönetmeliği (2001). Ankara:T.C. Resmi Gazete.

Onan, B. (2012). Dil eğitiminin temel kavramları. Ankara: Nobel Yayıncılık.

Özbay,M. (2005). Bir dil becerisi olarak dinleme eğitimi. Ankara: Akçağ Yayıncılık

Sever, S.(2004). Türkçe öğretimi ve tam öğrenme. Ankara: Anı Yayıncılık.

Solak, M. ve Yaylı, D. (2009). İlköğretim ikinci kademe Türkçe ders kitaplarının türler açısından incelenmesi. Uluslararası Sosyal Araştırmalar Dergisi, 2/9, 444-453.

Solmaz, M. (2011). Türkçe 6 Ders Notu. Ankara: M.E.B. Eğitim Teknolojileri Genel Müdürlüğü Yayınları.

Üründü, V. (2011). 6-8. sınıf Türkçe ders kitaplarının tema ve metin türü yönünden incelenmesi. İnönü Üniversitesi. Eğitim Bilimleri Enstitüsü. Yayınlanmamış Yüksek Lisans Tezi.

Yıldırım, A. ve Şimşek, H. (2011). Nitel araştırma yöntemleri. Ankara: Seçkin Yayıncılık.

http://aio.meb.gov.tr/sayfa.php?id=53 03.06.2013 tarihli erişim ile alınmıştır. 